\title{
Evaluation of the Physico-Chemical Properties of the Waters on the Litani River Station Quaraoun
}

\author{
Ali Hayek 1,2,3, Nabil Tabaja1,2, Samir Abbad Andaloussi' ${ }^{3}$, Joumana Toufaily ${ }^{1,2}$, \\ Evelyne Garnie-Zarli3 ${ }^{3}$ Abbas El Toufaili1,2, Tayssir Hamieh ${ }^{1,2 *}$
}

${ }^{1}$ Laboratory of Materials, Catalysis, Environment and Analytical Methods Laboratory (MCEMA), EDST, FS, Lebanese University, Hadath, Lebanon

${ }^{2}$ Laboratory of Applied Studies for Sustainable Development and Renewable Energy (LEADDER), EDST, Lebanese University, Hadath, Lebanon

${ }^{3}$ Laboratoire Sol Eau Systèmes Urbains (Leesu), Université Paris Est, Paris, France

Email: *tayssir.hamieh@ul.edu.lb

How to cite this paper: Hayek, A., Tabaja N., Andaloussi, S.A., Toufaily, J., GarnieZarli, E., El Toufaili, A. and Hamieh, T. (2020) Evaluation of the Physico-Chemical Properties of the Waters on the Litani River Station Quaraoun. American Journal of Analytical Chemistry, 11, 90-103.

https://doi.org/10.4236/ajac.2020.112007

Received: January 9, 2020

Accepted: February 16, 2020

Published: February 19, 2020

Copyright $\odot 2020$ by author(s) and Scientific Research Publishing Inc. This work is licensed under the Creative Commons Attribution International License (CC BY 4.0).

http://creativecommons.org/licenses/by/4.0/

\begin{abstract}
Water security is a very important purpose facing the world in the last decay as one of the main consequences related to the risks of climate change. Water quality of Litani River's at Quaraoun Lake station in Lebanon was evaluated by measuring various physicochemical parameters between 2008 and 2018 . Samples were performed and analyzed the first of every month. Different analytical methods were used to determine the values of 11 physico-chemical parameters. Different statistical methods, such as Principal Component Analysis and the Times Series Representation, were applied to the results to evaluate the water characteristics, determine the operation of the ecosystem and study the correlation between the different parameters in the Quaraoun station. Industrial, agricultural and sewage water pollution of the Litani River were demonstrated by the high concentration of sulfate, phosphate and ammonia. High bacterial activity was proved from the high decreasing of the dissolved oxygen. Important correlations between the different parameters and between the parameters of the ecosystem and the weather were proved.
\end{abstract}

\section{Keywords}

Litani River, Water Characteristics, Physico-Chemical Parameters, Statistical Analysis

\section{Introduction}

Water is a natural resource essential for life in any ecosystem [1]. Maintaining its 
quality is a major concern for the society which must meet the growing needs for water with the rapid development of the modern economy and the continuous expansion of population [2]. In fact, natural factors and human activities such as irrigation, industrial activities and sewage water introduce high amount of chemical and biological pollutants, directly or by ruff, to the surface water. As a result, the physico-chemical properties of rivers and other surface features are affected [3] [4] [5]. These influences lead to many disruptions to the natural environment and to an unpleasant ecosystem [6]. Hence the importance of studying the water quality by estimating the physicochemical quality of water which cannot be measured in a single way, but, by a set of parameters of different properties will be of our high interest Previous works focused on the water quality by measuring different parameters such as total dissolved solids, TDS and the concentration of phosphate sulfate, ammonia and other nutrients. Other researchers studied the effect of seasonal factors on the concentration of pollutants in the surface water especially the runoff during the periods of flooding [7] [8] [9] [10]. A relation between the nutrient loading to the rivers and the ecosystem has been reported by the Millennium Ecosystem Assessment [11].

Litani River is the most important river in Lebanese. Due to its geographic extension along the Bekaa Valey which constitutes the agricultural reservoir of Lebanon, passing through southern Lebanon, Litani River is a vital lifeline for the Lebanese community. The length of the river which is about $170 \mathrm{~km}$ has numerous tributaries including 30 main sources and around 140 wells managed by the administration and a very large number of small sources as well as more than 1200 wells which are also exploited by farmers [12]. It is divided into two parts, an upper part which begins from its multiple sources up to Qaraoun Lake (upper basin). The second part goes from Lake Qaraoun to the Mediterranean (lower basin) (Figure 1).

In recent decades, the water quality of the upper Litani basin has been deteriorated [13]. Unfortunately, this resource is subjected to a strong pollution exerted by the urban, industrial and agricultural development concentrated in its coastal zones. The study of the environmental problem which is linked to the water pollution in this river, notably Quaraoun Lake is not new [13] [14] [15]. The origins of pollution, its effects on the natural environment, as well as the consequences on water quality are now well documented. The importance of Quaraoun Lake is in its contribution to the irrigation of agricultural land in southern Lebanon and in the Bekaa region [16]. The interest of this article returns to the study of a number of physicochemical properties in a large scale (long duration arriving to 11 years), it is therefore possible to assess the evolution of the water quality at Quaraoun Lake of the Litani River. By measuring various physico-chemical parameters in this long duration, we can study the development of the pollution resources in the region and determine their types in which the most important is to determine the correlation between the different parameters and between the parameters and the climate impact. This article is 


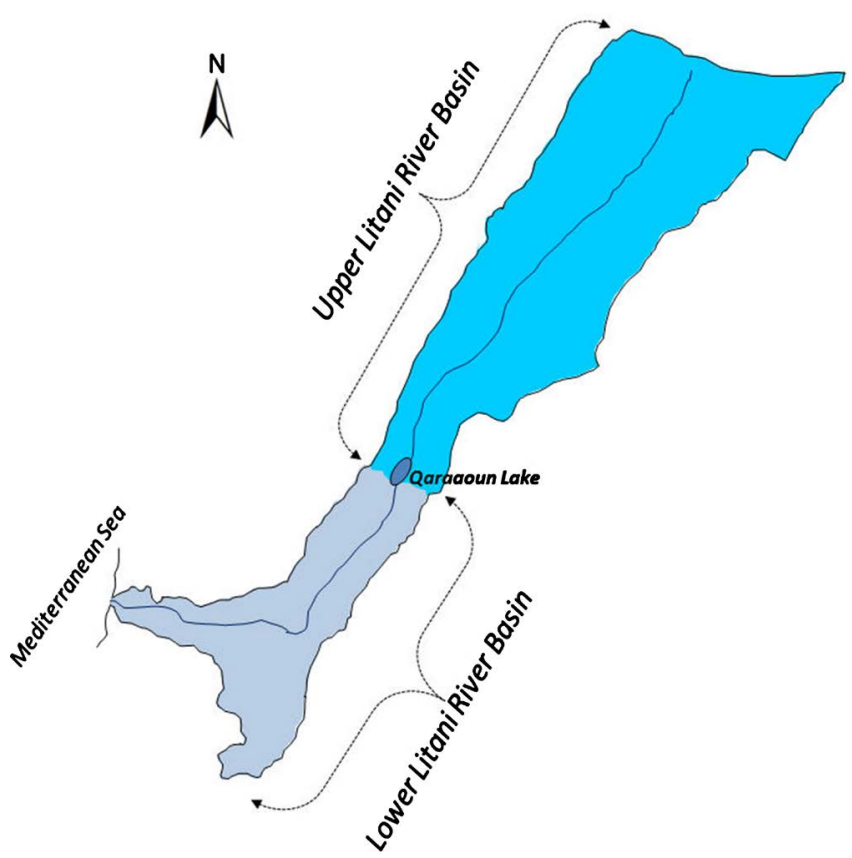

Figure 1. A representative map shows the two main basins of the Litani River separated by Quaraoun Lake.

divided into several sections: First, we present the sampling method used for water withdrawals over different periods. Then we analyze the physicochemical parameters in a global view of the functioning of the Litani river over the years. In the following, the exploitation of the data which was only possible by using statistical methods was adopted to calculate the correlation coefficients in order to study the relationship between the physico-chemical parameters. The analysis was carried out using annual averages of 11 parameters obtained during sampling at the Qaraoun station.

\section{Materials and Methods}

\subsection{Site Description}

Qaraoun Lake (Middle of Litani River), situated at the coordinate: N33 $33^{\prime} 309^{\prime \prime}$, E35 $42^{\prime} 024^{\prime \prime}$, with an elevation of $864 \mathrm{~m}$ above the sea level is the biggest lake in Lebanon with a total capacity of 220 million $\mathrm{m}^{3}$.

\subsection{Sampling Test}

All samplings were taken from the same points of Lake Qaraoun (N33 $33^{\prime} 309^{\prime \prime}$, $\left.\mathrm{E} 35^{\circ} 42^{\prime} 024^{\prime \prime}\right)$. The same sampling method was used for all samples, at a distance of $2 \mathrm{~m}$ from the side and $20 \mathrm{~cm}$ deep from the free surface of the water. Each sample consists of 5 trials, while each measurement was performed 5 times and the average was recorded. These samples were taken at the beginning of each month.

\subsection{Measurement Method}

In the following section, we present the parameters, the measurement location, 
the instrument used, the period, the date and the numbers of the samples.

\section{Results and Discussions}

\subsection{Annual and Quarterly Variation of the Parameters}

The study of the average annual values of each parameter was calculated and the variations of the annual means of the parameters were plotted. Figure 2 shows the variations of the average annual quantity of the physicochemical parameters over the 11 years between 2008 and 2018 at the Quaraoun site of the Litani River. These graphs were carried out to evaluate the evolution of the essential characteristics of the river, to determine the nature and sources of the pollution and to study the mode of functioning of the ecosystem and its evolution and its future on the Quaraoun station. The parameters are divided into four categories according to the ranges of the variations of their values during the 11 years of the study (Table 1).

Table 1. Description method of sampling of parameters.

\begin{tabular}{|c|c|c|c|c|c|c|}
\hline Parameters & Description & $\begin{array}{l}\text { Testing } \\
\text { situation }\end{array}$ & Instruments & $\begin{array}{l}\text { Sampling } \\
\text { Period }\end{array}$ & Data Period & $\begin{array}{l}\text { Number } \\
\text { of } \\
\text { Samples }\end{array}$ \\
\hline $\mathrm{T}\left({ }^{\circ} \mathrm{C}\right)$ & Temperature & In-Situ & Thermometer & $\begin{array}{l}\text { One Sample } \\
\text { Every Month }\end{array}$ & Jan.-2008 to Dec. -2018 & 132 \\
\hline $\mathrm{pH}$ & $\begin{array}{l}\text { Potential } \\
\text { hydrogen }\end{array}$ & $\begin{array}{l}\text { In-Situ+ } \\
\text { In Lab }\end{array}$ & pH meter, La Motte & $\begin{array}{l}\text { One Sample } \\
\text { Every Month }\end{array}$ & Jan.-2008 to Dec.-2018 & 132 \\
\hline $\mathrm{EC}(\mu \mathrm{S} / \mathrm{cm})$ & $\begin{array}{l}\text { Electrical } \\
\text { Conductivity }\end{array}$ & In-Situ & Conductivity Meter, La Motte & $\begin{array}{l}\text { One Sample } \\
\text { Every Month }\end{array}$ & Jan.-2008 to Dec.-2018 & 132 \\
\hline TDS (mg/l) & $\begin{array}{l}\text { Total Dissolved } \\
\text { Solids }\end{array}$ & In-Situ & TDS Meter, La Motte & $\begin{array}{l}\text { One Sample } \\
\text { Every Month }\end{array}$ & Jan.-2008 to Dec.-2018 & 132 \\
\hline $\mathrm{SO}_{4}^{2-} \quad(\mathrm{mg} / \mathrm{l})$ & Sulfate & In Lab & $\begin{array}{l}\text { Spectrophotometry. Method H3450-QNT. } \\
\text { Powder pillows Hach } 8051 \text { Cat number } 2106769\end{array}$ & $\begin{array}{l}\text { One Sample } \\
\text { Every Month }\end{array}$ & Jan.-2008 to Dec.-2018 & 132 \\
\hline $\mathrm{NO}^{2-}(\mathrm{mg} / \mathrm{l})$ & Nitrite & In Lab & $\begin{array}{l}\text { Spectrophotometry. Method H2610. FXD } \\
\text { Nitrite, low range, Diazotisation method, } \\
\text { powder pillows. Hach } 8507 \text {. NitriVer } 3\end{array}$ & $\begin{array}{l}\text { One Sample } \\
\text { Every Month }\end{array}$ & Jan.-2008 to Dec. -2018 & 132 \\
\hline $\mathrm{NO}^{3-}(\mathrm{mg} / \mathrm{l})$ & Nitrate & In Lab & $\begin{array}{l}\text { Spectrophotometry. Method H2520. QNT } \\
\text { Nitrate, Mid range, Cadmium reduction } \\
\text { method, powder pillows. Hach method } 8171 \\
\text { Nitra Ver } 5\end{array}$ & $\begin{array}{l}\text { One Sample } \\
\text { Every Month }\end{array}$ & Jan.-2008 to Dec. -2018 & 132 \\
\hline $\mathrm{PO}_{4}^{3-} \quad(\mathrm{mg} / \mathrm{l})$ & Phosphate & In Lab & $\begin{array}{l}\text { Spectrophotometry. Method H3035-QNT, } \\
\text { Phosphorous, reactive, PhosVer 3, Test N, tube } \\
\text { procedure. Hach } 8048 \text { Cat number } 2106069\end{array}$ & $\begin{array}{l}\text { One Sample } \\
\text { Every Month }\end{array}$ & Jan.-2008 to Dec. -2018 & 132 \\
\hline $\mathrm{NH}_{3}(\mathrm{mg} / \mathrm{l})$ & Ammonia & In Lab & $\begin{array}{l}\text { Ammonia Ionic strength adjuster, powder } \\
\text { pillows. Cat } 2980699 \text {. Ion selective electrode }\end{array}$ & $\begin{array}{l}\text { One Sample } \\
\text { Every Month }\end{array}$ & Jan. -2008 to Dec. -2018 & 132 \\
\hline Salinity (mg/l) & Salinity & In Lab & Sal Portable meter, La Motte & $\begin{array}{l}\text { One Sample } \\
\text { Every Month }\end{array}$ & Jan.-2008 to Dec. -2018 & 132 \\
\hline
\end{tabular}



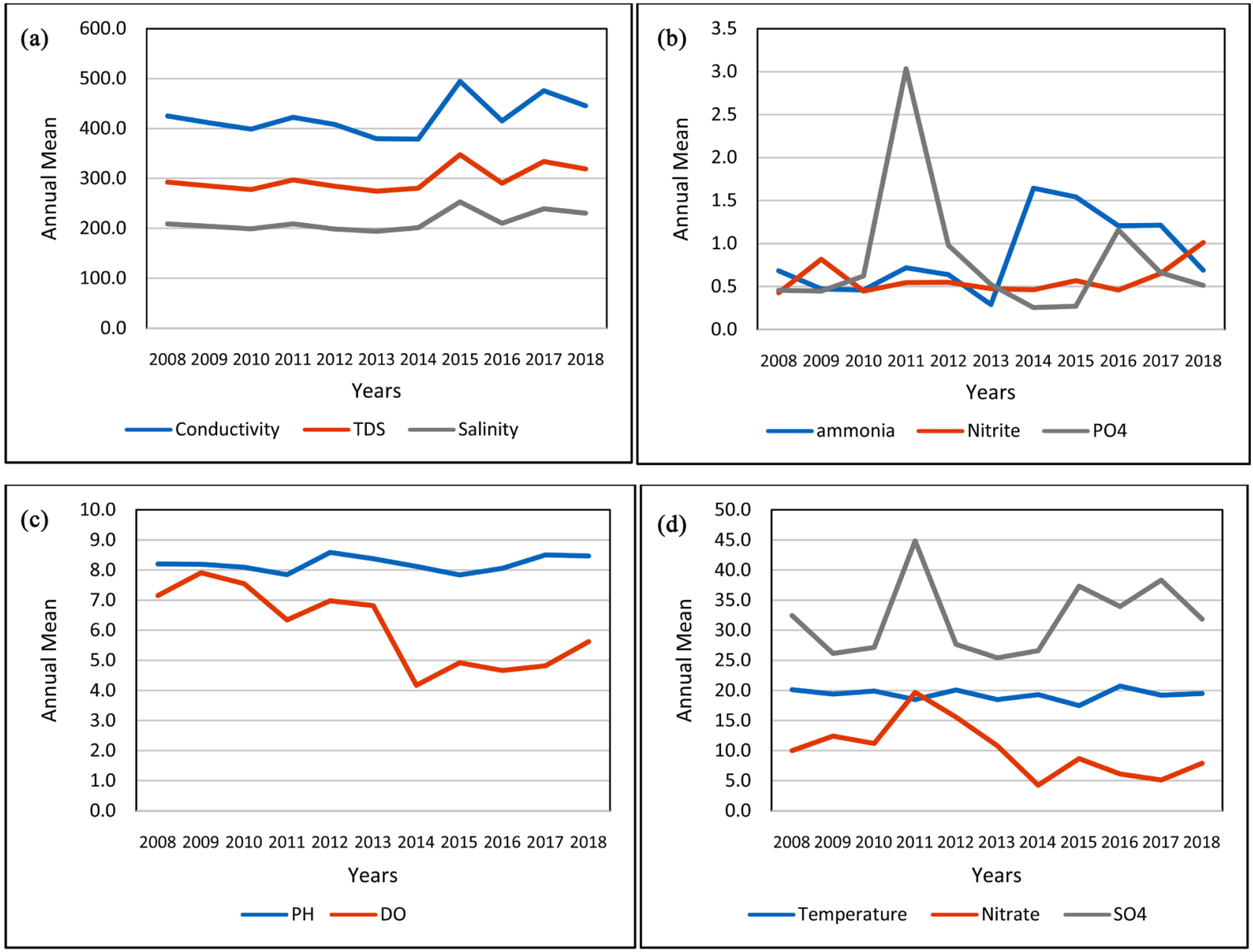

Figure 2. Evolution of the annual means between 2008 and 2018.

The study of the evolution of the values of all the parameters shows an imbalance which results in decreasing and increasing. But overall, on the slope of evolution, we notice an increase in all parameters. This confirms the development of the pollution sources in the vicinity of the river. According to the figures, three zones can be distinguished whose pollution rate is very high. The first zone is between 2010 and 2013, in which a large increase in the concentration of phosphate, nitrate and sulfate and an increase in the $\mathrm{pH}$ of the water were observed. A peak was reached in 2011, then the values of these parameters gradually decrease until 2013. The origin of phosphate is usually from wastewater and domestic water. This confirms a highly developed human activity related to a huge population development next to the river in the same period of the Syrian crisis. This demographic development is accompanied by an industrial and agricultural development accompanied by the increase of the concentrations of sulfate and nitrogen products respectively. In this zone, a slight increase in conductivity, TDS and salinity was observed. The second zone is between 2013 and 2016, this zone is characterized by a large decrease in phosphate concentration and a large increase in the concentrations of ammonia and sulfate. A slight in- 
crease in nitrate in 2015 and a slight increase in TDO in this year have been detected. In the same year, a significant increase in conductivity, TDS and salinity was observed. These results confirm the reduction of pollution by wastewater and domestic water, but a significant development of agricultural and industrial activity is estimated. The third zone is between 2016 and 2018. This zone is characterized by a significant increase in phosphate concentration in 2016, this concentration is gradually decreasing. Ammonia concentration decreases progressively while nitrite and nitrate concentrations increase was observed. This nitrogen cycle is accompanied by a slight increase in the rate of TDO in this zone. An increase in sulfate concentration was detected. These increases are accompanied by increases in TDS, conductivity, and salinity. These results confirm the development of agricultural and industrial activity and an increase in the rate of wastewater and domestic waste discharged into the river without any treatment.

\subsection{Statistical Study of Physicochemical Parameters}

\subsubsection{Annual Variation}

Table 2 represents the statistical elements calculated on all the values obtained on all physicochemical parameters during the period studied between 2008 and 2018. The results obtained are significant, representative and confirm the results observed for the annual means that are studied in Figure 2. A large difference between the minimum and maximum values has been observed for ammonia, nitrite, nitrate, sulfate and phosphate accompanied by a smaller difference in TDS, salinity and conductivity. These results are consistent with the sharp increases in 2011 and 2016 (Figure 2). The coefficients of variation of these parameters, summarized in Table 2, confirm this interpretation. The first quartile and the third quartile show that these high values are sustainable and not due to immediate exposures. For phosphate, it is observed that the minimum value is $0.26 \mathrm{mg} \cdot \mathrm{L}^{-1}$ and the maximum value is $3.03 \mathrm{mg} \cdot \mathrm{L}^{-1}$ while more than $25 \%$ of the values of the phosphate concentration are greater than $0.84 \mathrm{mg} \cdot \mathrm{L}^{-1}$. The same observation is confirmed for ammonia and sulfate.

Table 2. Descriptive statistics for parameters.

\begin{tabular}{|c|c|c|c|c|c|c|c|c|c|c|c|}
\hline Statistic & $\begin{array}{c}\text { Temperature } \\
{ }^{\circ} \mathrm{C}\end{array}$ & $\mathrm{pH}$ & $\begin{array}{l}\mathrm{DO} \\
\mathrm{mg} / 1\end{array}$ & $\begin{array}{l}\text { Conductivity } \\
\text { microS/cm }\end{array}$ & $\begin{array}{l}\text { TDS } \\
\mathrm{mg} / 1\end{array}$ & $\begin{array}{l}\text { Salinity } \\
\mathrm{mg} / \mathrm{l}\end{array}$ & $\begin{array}{c}\text { ammoniac } \\
\mathrm{mg} / \mathrm{l}\end{array}$ & $\begin{array}{l}\text { Nitrite } \\
\mathrm{mg} / \mathrm{l}\end{array}$ & $\begin{array}{l}\text { Nitrate } \\
\mathrm{mg} / 1\end{array}$ & $\begin{array}{l}\left(\mathrm{SO}_{4}\right) \\
\mathrm{mg} / \mathrm{l}\end{array}$ & $\begin{array}{l}\left(\mathrm{PO}_{4}\right) \\
\mathrm{mg} / 1\end{array}$ \\
\hline Minimum & 17.50 & 7.83 & 4.17 & 378.75 & 274.25 & 194.33 & 0.28 & 0.43 & 4.25 & 25.42 & 0.26 \\
\hline Maximum & 21.09 & 8.63 & 7.91 & 496.57 & 357.14 & 258.71 & 1.64 & 1.42 & 19.67 & 44.83 & 3.03 \\
\hline $1^{\text {st }}$ Quartile & 18.71 & 8.07 & 4.82 & 403.17 & 282.17 & 200.50 & 0.56 & 0.45 & 6.53 & 26.88 & 0.45 \\
\hline Median & 19.33 & 8.19 & 5.94 & 413.00 & 288.18 & 208.92 & 0.69 & 0.55 & 10.00 & 32.42 & 0.53 \\
\hline $3^{\text {rd }}$ Quartile & 20.00 & 8.44 & 7.06 & 456.46 & 319.73 & 227.48 & 1.26 & 0.62 & 11.79 & 35.94 & 0.84 \\
\hline Mean & 19.33 & 8.22 & 6.02 & 428.57 & 302.31 & 216.66 & 0.88 & 0.62 & 10.03 & 32.35 & 0.81 \\
\hline Standard deviation & 0.98 & 0.28 & 1.32 & 43.93 & 30.82 & 23.66 & 0.47 & 0.29 & 4.70 & 6.37 & 0.79 \\
\hline Variation coefficient & 0.05 & 0.03 & 0.21 & 0.10 & 0.10 & 0.10 & 0.51 & 0.45 & 0.45 & 0.19 & 0.93 \\
\hline
\end{tabular}




\subsubsection{Seasonal Variation}

The average values of the parameters are significant to understand the general evolution of the physico-chemical parameters and to study the evolution of the water quality of the river and the lake as well as the development of the sources of the pollution and their natures. Other factors can influence the quality of water, the most important of these factors is the amount of precipitation. A statistical study was carried out to take into consideration the effect of the amount of precipitation on the values of the physicochemical parameters of the water. The results are summarized in Table 3 and are represented by the histograms of Figure 3 in

Table 3. Seasonal variation of the different physico-chemical parameters.

\begin{tabular}{|c|c|c|c|c|c|c|c|c|c|c|c|c|}
\hline \multicolumn{2}{|l|}{ Season } & \multirow{2}{*}{$\begin{array}{c}\text { Temperature } \\
16.98\end{array}$} & \multirow{2}{*}{$\begin{array}{l}\mathrm{pH} \\
7.95\end{array}$} & \multirow{2}{*}{$\begin{array}{l}\mathrm{DO} \\
6.02\end{array}$} & \multirow{2}{*}{$\begin{array}{c}\text { Conductivity } \\
470.62\end{array}$} & \multirow{2}{*}{$\begin{array}{c}\text { TDS } \\
330.43\end{array}$} & \multirow{2}{*}{$\begin{array}{l}\text { Salinity } \\
233.08\end{array}$} & \multirow{2}{*}{$\begin{array}{c}\text { Ammonia } \\
1.28\end{array}$} & \multirow{2}{*}{$\begin{array}{c}\text { Nitrite } \\
0.68\end{array}$} & \multirow{2}{*}{$\begin{array}{c}\text { Nitrate } \\
9.88\end{array}$} & \multirow{2}{*}{$\begin{array}{l}\mathrm{SO}_{4}^{2-} \\
34.12\end{array}$} & \multirow{2}{*}{$\frac{\mathrm{PO}_{4}^{3-}}{1.64}$} \\
\hline Wet & Mean & & & & & & & & & & & \\
\hline & $\mathrm{SD}$ & 2.46 & 0.44 & 1.23 & 72.82 & 50.30 & 38.38 & 0.84 & 0.42 & 7.20 & 35.63 & 4.42 \\
\hline \multirow[t]{2}{*}{ Semi dry/wet } & Mean & 19.42 & 8.21 & 6.14 & 423.37 & 298.56 & 215.91 & 0.85 & 0.59 & 10.27 & 30.30 & 0.58 \\
\hline & $\mathrm{SD}$ & 1.97 & 0.54 & 1.92 & 80.94 & 58.00 & 43.13 & 0.71 & 0.89 & 6.05 & 6.99 & 0.68 \\
\hline \multirow[t]{3}{*}{ Dry } & Mean & 22.85 & 8.55 & 6.04 & 361.02 & 255.25 & 182.62 & 0.46 & 0.45 & 9.79 & 30.54 & 0.32 \\
\hline & $\mathrm{SD}$ & 2.91 & 0.60 & 1.91 & 52.65 & 38.26 & 28.90 & 0.42 & 0.19 & 5.84 & 7.79 & 0.46 \\
\hline & Sig. & 0.00 & 0.00 & 0.93 & 0.00 & 0.00 & 0.00 & 0.00 & 0.33 & 0.88 & 0.46 & 0.00 \\
\hline
\end{tabular}
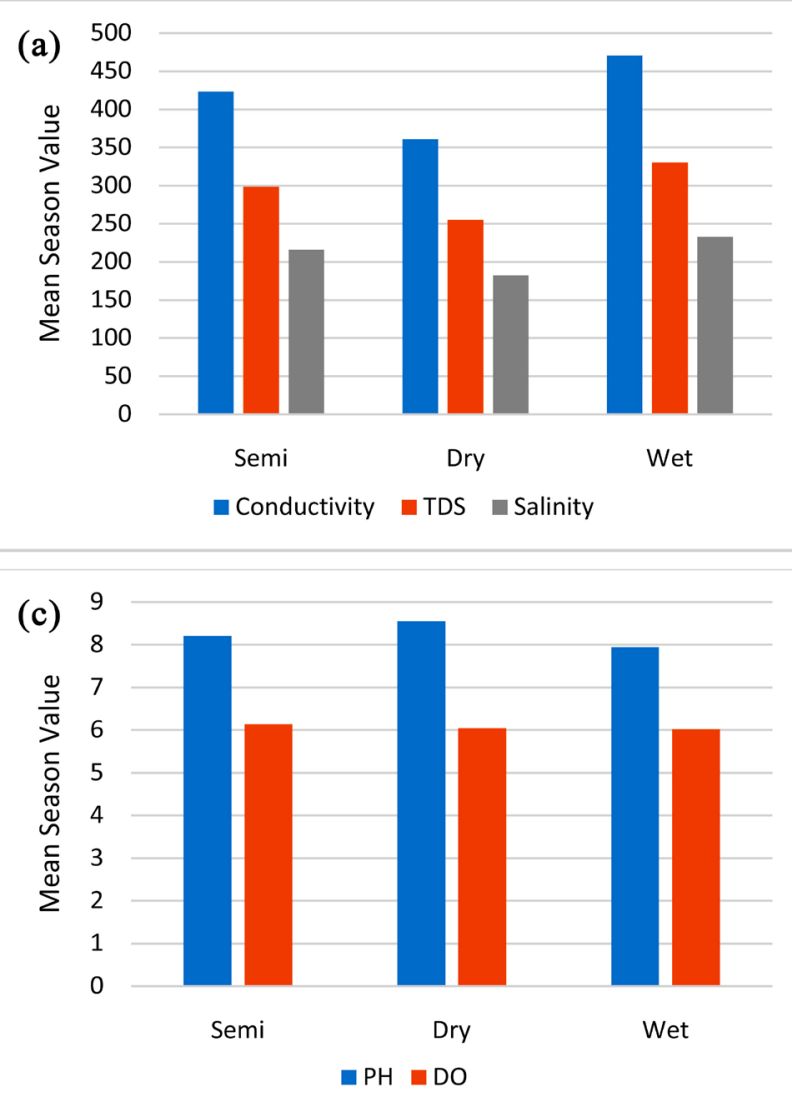
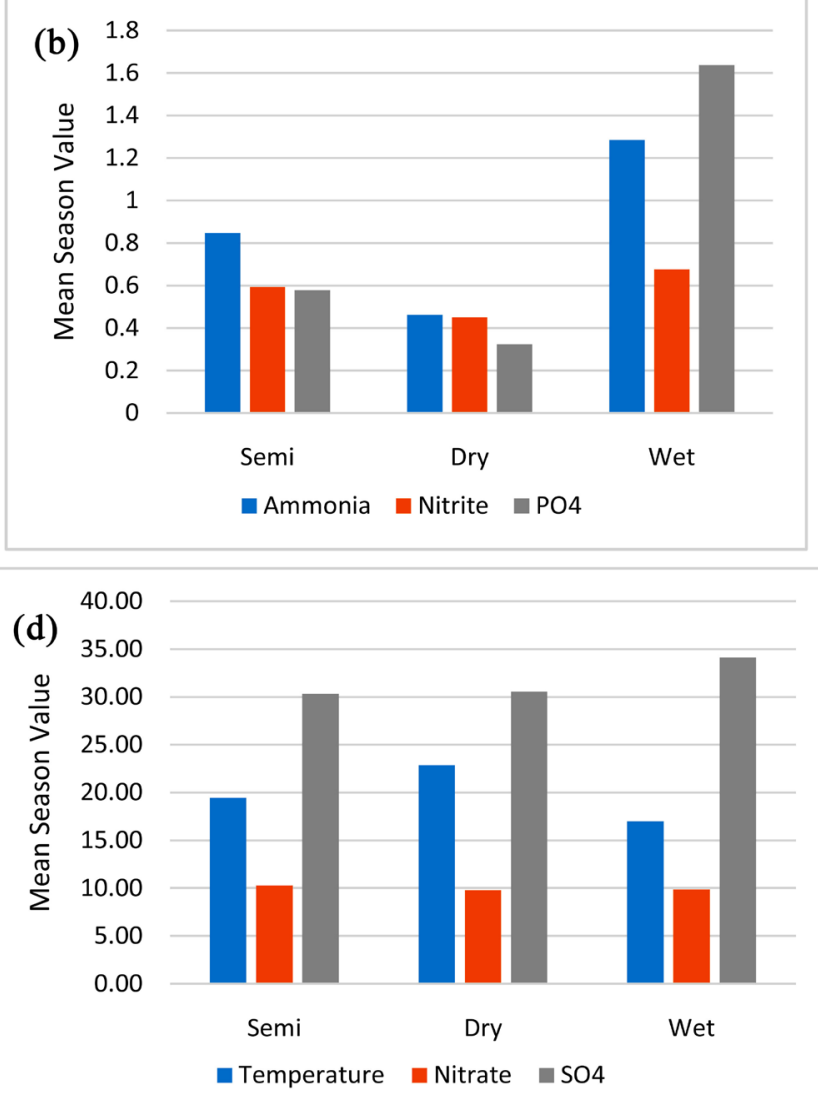

Figure 3. Quarterly evolution of the means of the physico-chemical parameters. 
which the parameters are divided into four groups according to the ranges of these average values. Each year has been divided into three seasons (dry, semi dry/wet and wet). The dry months are the months of summer (6, 7 and 8). The wet months are the months of winter $(12,1$ and 2) while the semi dry/wet months are the months of autumn and spring (3, 4, 5, 9, 10 and 11). A seasonal average was calculated for each year, then a seasonal average over the 10 years of the study was calculated. TDO and nitrate concentration are the least affected by the variation of seasonal conditions (temperature and precipitation) with a significance (sig. $=0.93)$ and (sig. $=0.88)$ respectively. Two other parameters have a little more affected by these variations, these parameters are nitrite and sulfate with a significance equal to 0.33 and 0.46 respectively. The other parameters are very affected by seasonal variations with (sig. $=0$ ). Conductivity, TDS, and salinity are influenced by precipitation as the rate of erosions and sediments increases to the river with runoff increasing the concentration of magnesium, sodium, and potassium ions and other inorganic products like carbonate, bicarbonate, sulfate and chloride and therefore increase the turbidity of the water. The resulting runoff of the precipitation increases the amount of ammonia, sulfate and phosphate that reaches the river [17]. So, we observe an increase in the concentrations of these anions in water.

\subsection{Multivariate Statistical Analysis}

\subsubsection{Correlations between the Parameters}

The exploitation of the data was only possible through the use of statistical methods, by calculating the correlation coefficient in order to study the relationship between the physicochemical parameters by using the Principal Component Analysis (PCA) [18]. The contribution of the correlation between physicochemical parameters allows giving an approach on the common origin of certain parameters. The results of this study are summarized in Table 4 .

Table 4. Correlation matrix between the parameters.

\begin{tabular}{|c|c|c|c|c|c|c|c|c|c|c|}
\hline Parameters (Annual) & $\begin{array}{c}\text { Temperature } \\
{ }^{\circ} \mathrm{C}\end{array}$ & $\mathrm{DO} \mathrm{mg} / \mathrm{l}$ & $\begin{array}{l}\text { Conductivity } \\
\text { microS/cm }\end{array}$ & $\begin{array}{l}\mathrm{TDS} \\
\mathrm{mg} / \mathrm{l}\end{array}$ & $\begin{array}{l}\text { Salinity } \\
\mathrm{mg} / \mathrm{l}\end{array}$ & $\begin{array}{c}\text { ammonia } \\
\mathrm{mg} / \mathrm{l}\end{array}$ & $\begin{array}{l}\text { Nitrite } \\
\mathrm{mg} / \mathrm{l}\end{array}$ & $\begin{array}{l}\text { Nitrate } \\
\mathrm{mg} / \mathrm{l}\end{array}$ & $\begin{array}{c}\left(\mathrm{SO}_{4}^{2-}\right) \\
\mathrm{mg} / \mathrm{l}\end{array}$ & $\begin{array}{c}\left(\mathrm{PO}_{4}^{3-}\right) \\
\mathrm{mg} / \mathrm{l}\end{array}$ \\
\hline Temperature ${ }^{\circ} \mathrm{C}$ & 1 & & & & & & & & & \\
\hline DO mg/l & 0.160 & 1 & & & & & & & & \\
\hline Conductivity microS/cm & -0.389 & -0.355 & 1 & & & & & & & \\
\hline TDS mg/l & -0.452 & -0.456 & 0.980 & 1 & & & & & & \\
\hline Salinity mg/l & -0.433 & -0.484 & 0.973 & 0.995 & 1 & & & & & \\
\hline Ammonia mg/l & -0.164 & -0.880 & 0.325 & 0.381 & 0.419 & 1 & & & & \\
\hline Nitrite mg/l & -0.140 & -0.025 & 0.607 & 0.655 & 0.645 & -0.158 & 1 & & & \\
\hline Nitrate $\mathrm{mg} / \mathrm{l}$ & -0.139 & 0.613 & -0.256 & -0.330 & -0.390 & -0.604 & -0.103 & 1 & & \\
\hline$\left(\mathrm{SO}_{4}^{2-}\right) \mathrm{mg} / \mathrm{l}$ & -0.320 & -0.457 & 0.627 & 0.593 & 0.567 & 0.338 & 0.152 & 0.143 & 1 & \\
\hline$\left(\mathrm{PO}_{4}^{3-}\right) \mathrm{mg} / \mathrm{l}$ & -0.030 & -0.020 & -0.102 & -0.138 & -0.186 & -0.153 & -0.127 & 0.679 & 0.634 & 1 \\
\hline
\end{tabular}

Values in bold are different from 0 with a significance level alpha $=0.05$. 
Referring to Table 4, we observe that temperature is an independent parameter while a strong correlation exists between TDS, salinity and conductivity with correlation factors greater than 0.9 (0.98 and 0.97). This is a normal result because the three parameters are influenced by the same conditions that are summarized. Consequently, significant correlation factors are observed between these parameters (TDS, salinity and conductivity) with the concentrations of nitrite and sulfate (of the order of 0.6). The correlation between TDS, salinity and conductivity is negative with temperature due to seasonal conditions especially the precipitation. In the rainy months, the temperature decreases and the precipitation rate increases which lead to a significant runoff towards the water currents, which increases the turbidity of the water and consequently of the TDS, the salinity and the conductivity. The opposite phenomenon is detected in dry months, when temperatures rise and the precipitation rate decreases. To explain the relationship between nitrogen products (ammonia, nitrite and nitrate) it is necessary to rely on the nitrogen cycle. The main source of ammonia (and ammonium) in water is the agriculture. These products exist in fertilizers, and then it gets to surface water with runoff. The nitrogen cycle is important and it is the origin of the balance between the different forms of nitrogen products (ammonium, nitrate and nitrite). Ammonium is transformed into nitrite (bacterial nitrification). The latter oxidizes to nitrate. Nitrate is the least toxic form, while nitrite is the most toxic form. An increase in bacterial activity promotes the transformation of ammonium into nitrite. A high level of oxygen promotes the oxidation of the latter to nitrate. Then a decrease in the oxygen level in the water leads to an increase in the concentration of ammonium (and an increase in the $\mathrm{pH}$ of the medium) and nitrite because of the important bacterial activity and to a decrease in the concentration of nitrate. This interpretation results in a positive correlation of ammonia, $\mathrm{pH}$, and nitrite and a negative correlation of ammonia and nitrite with TDO and nitrate. There is a strong positive correlation between TDO and nitrate because high levels of TDO increase the rate of oxidation of nitrite to nitrate. With regard to phosphate, the correlation with sulfate comes from the fact that the development of industrial pollution and that of pollution by wastewater and domestic water are simultaneous (2011 and 2016 in Figure 2 for example). Another very important correlation exists between phosphate, TDO and nitrate which cannot be observed in Table 3 . This relationship can be detected in Figure 3, where the TDO and nitrate concentration decrease with increasing phosphate concentration. Phosphate, with nitrogenous products (ammonia and ammonium, etc.), is the cause of the eutrophication phenomenon. This phenomenon is characterized by excessive growth of plants and algae due to the high availability of nutrients. It is directly related to a decrease in the level of oxygen in water. This slows the conversion of ammonium to nitrite and the oxidation of the latter to nitrate, which is the least toxic. And as a result, it leads to an increase in the $\mathrm{pH}$ of the middle. But this correlation is not shown in Table 4 because the TDO and the nitrate concentration continue to decrease after the 
re-decrease in phosphate concentration. This phenomenon is due to the fact that the algae continue to develop for a few years during the decrease of the phosphate concentration The TDO is re-increasing with the decrease in phosphate between 2017 and 2018. We also note that a strong correlation values mean that over the 11 years of study, these parameters have varied in the same direction and that the relationship between them is almost linear.

\subsubsection{Principal Component Analysis PCA}

The main component analysis aims to reduce the number of numerical variables to be analyzed by grouping their information on a strictly lower number of new variables called main components [19].

In our study, we have introduced 11 physico-chemical parameters that we have available and will be studied over a period between 2008 and 2018. The table below gives in the Extraction column, the percentage of information for each of the 11 variables which are reproduced by the model. First, Kaiser's criterion leads us to select two axes, which retains $63.47 \%$ of the total inertia.

Then, we can deduce from Table 5, the variables "Temperature", "DO", "Conductivity", "TDS", "Salinity", "Ammonia" and "Nititre" contribute on axis 1. Similarly, we notice that all the remaining variables are well represented on axis 2 , which gives $63.47 \%$ of the initial information, which is a completely satisfactory level for this type of analysis.

Table 5. Total explained variance.

\begin{tabular}{cccc}
\hline \multirow{2}{*}{ Component } & \multicolumn{3}{c}{ Initial Eigenvalues } \\
\cline { 2 - 4 } & Total & \% of Variance & Cumulative \% \\
\hline 1 & 4.638 & 42.165 & 42.165 \\
2 & 2.343 & 21.301 & 63.466 \\
\hline
\end{tabular}

Table 6. Component matrix.

\begin{tabular}{ccc}
\hline & \multicolumn{2}{c}{ Component } \\
\cline { 2 - 3 } & \multicolumn{1}{c}{$\mathbf{1}$} \\
\hline Temperature ${ }^{\circ} \mathrm{C}$ & -0.441 & -0.336 \\
$\mathrm{PH}$ & 0.088 & -0.719 \\
$\mathrm{DO} \mathrm{mg} / \mathrm{l}$ & -0.658 & -0.147 \\
Conductivity microS/cm & 0.924 & -0.004 \\
TDS mg/l & 0.966 & -0.044 \\
Salinity $\mathrm{mg} / \mathrm{l}$ & 0.974 & -0.069 \\
Ammonia $\mathrm{mg} / \mathrm{l}$ & 0.584 & 0.134 \\
Nitrite $\mathrm{mg} / \mathrm{l}$ & 0.553 & -0.348 \\
$\mathrm{Nitrate} \mathrm{mg} / \mathrm{l}$ & -0.470 & 0.575 \\
$\left(\mathrm{SO}_{4}\right) \mathrm{mg} / \mathrm{l}$ & 0.618 & 0.702 \\
$\left(\mathrm{PO}_{4}\right) \mathrm{mg} / \mathrm{l}$ & -0.138 & 0.850 \\
\hline
\end{tabular}

Extraction Method: Principal Component Analysis. 
Finally, to restore the physicochemical parameters we draw the correlation circle using PCA and we obtain the following Figure 4.

While the points constitute a cloud of which only 2 axes realize $63.46 \%$ of the inertia (Table 5). The first, axis (component 1) is characterized by a percentage of inertia of $42.165 \%$. The parameters (DO, Conductivity, TDS, Salinity, Ammonia, Nitrite) are the best correlated to the axis which shows a significant correlation $( \pm 0.5$ to \pm 0.93$)$ with axis 1 (Table 6 ).

From the figure above (correlation circle), we can see that the parameters "conductivity", "TDS" and "Salinity" are very close to the correlation circle and therefore very well represented on the mapping. The rather closed-angle (starting from the origin) formed by the 3 points indicates that these 3 variables are fairly well correlated with each other. On the other hand, the almost right angle formed by the three variables respectively by " $\mathrm{PO}_{4}$ ", and " $\mathrm{PH}$ " indicates that these three variables are independent of " $\mathrm{PO}_{4}$ " and " $\mathrm{PH}$ ". The fact that these three variables are close to axis 1 indicates that they are very well represented by this axis. As they are very far from axis 2 , we can conclude that they are little represented by this axis. It can be deduced that a huge increase in the amount of wastewater exposed in the river leads to a significant increase in the phosphate concentration in the water. In addition, phosphate is directly linked to a decrease in the level of oxygen (TDO) in water. This slows the conversion of ammonium to nitrite and the oxidation of the latter to nitrate, which is the least toxic. And as a result, it leads to an increase in the $\mathrm{pH}$ of the medium. This increase in $\mathrm{pH}$

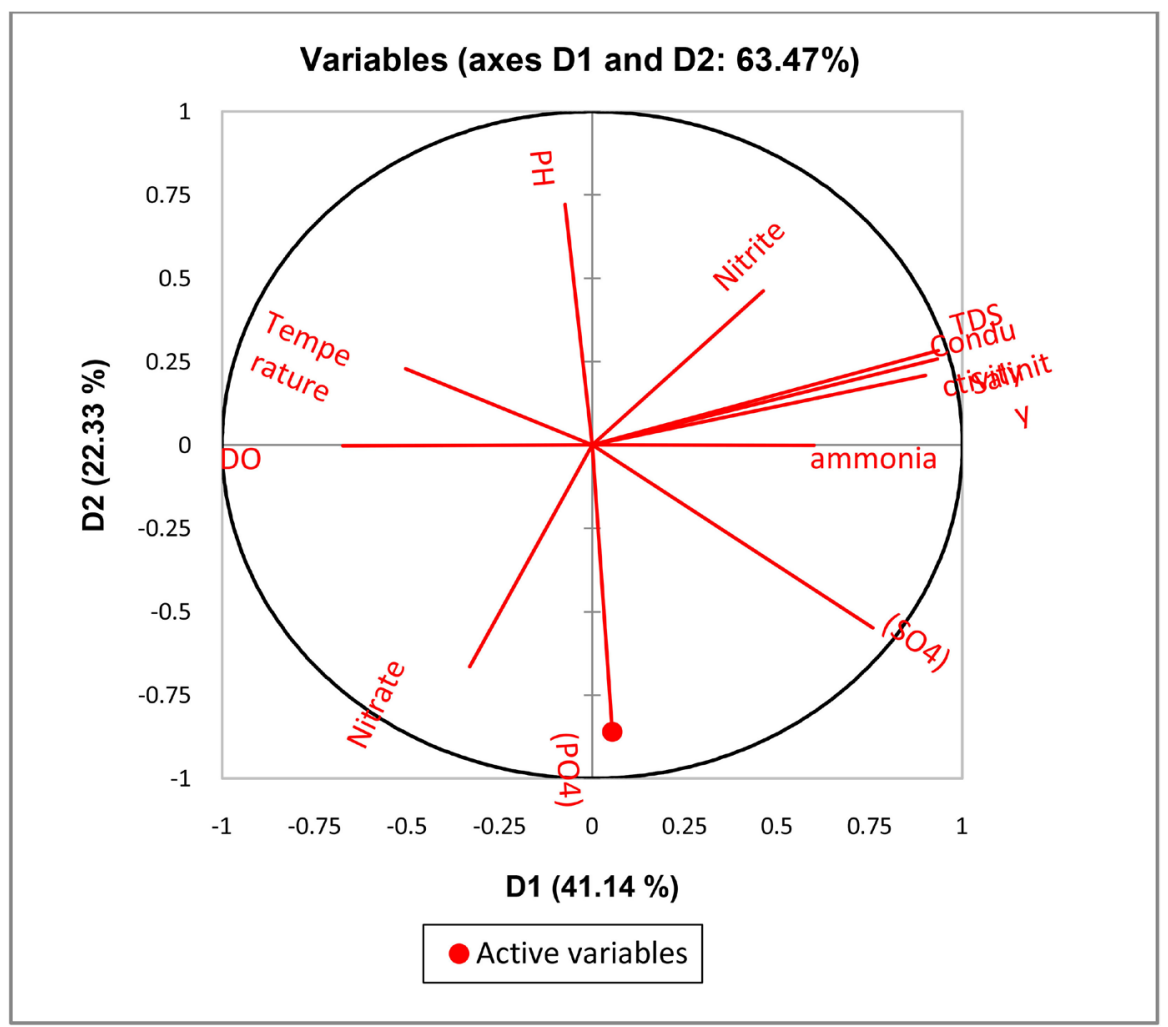

Figure 4. Correlation circle of the parameters. 
decreases the rate of dissociation of mineral salts and promotes this precipitation, which leads to a decrease in TDS.

Axis 1 (D1) opposes the physicochemical parameters "conductivity, TDS, Salinity, Ammonia, Nitrite" to the "DO" parameter. This axis is therefore the first main component, measuring the distribution between the parameters. Note that 6 out of 11 parameters are well represented on axis 1 (table: the quality of representation is equal to the squared coordinate, for example, the quality of representation of the TDS parameter is equal to $\left(0.966^{2}\right)=0.933$.

Regarding axis 2, the parameters " $\mathrm{PO}_{4}$ ", " $\mathrm{PH}$ " are very well correlated with the axis. The parameters "Nitrate", "Temperature" are also correlated but to a lesser extent.

The main origin of sulfate in water is naturally the mullions which are used in industry. So the origin of sulfate in water is industrial water exposed directly in the river. Sulfite oxidizes to sulfate, so a decrease in the oxygen level in the water slows this oxidation, which decreases the concentration of the sulfate and leads to an increase in the concentration of the sulfite [20]. The decrease in phosphate concentration is directly related to a decrease in the $\mathrm{pH}$ of the medium.

A high level of oxygen promotes the oxidation of the latter to nitrate. Then a decrease in the oxygen level in the water due to eutrophication, decreases the bacterial activity and then leads to an increase in the ammonium concentration (increase in the $\mathrm{pH}$ of the medium) and a decrease in the concentrations nitrite and nitrate.

\section{Conclusion}

Annual average values show that the sources of pollution of the Litani River and the subsequent Quaraoun Lake are diverse. High concentrations of sulfate, ammonia and phosphate were detected. These anions come from human activities, wastewater and domestic waters are the origin of phosphate. Industrial activities are the main source of sulfate and agricultural activities are the origin of nitrogen products. Other seasonal conditions influence the physicochemical parameters, especially precipitation, which increases the rate of runoff and consequently the organic and inorganic products that come to the river which increases the turbidity of the water and the rate of pollution (sulfate, phosphate, ammonia, TDS, salinity and conductivity). These pollutions are durable and not immediate. Correlations between different parameters were shown by statistical studies reflecting strong positive relationships between TDS, salinity, conductivity, nitrite, nitrate and sulfate. Negative correlations occur between ammonia and nitrite with nitrate. The latter has a strong positive correlation with TDO. A significant negative relationship has been shown between phosphate and TDO that strongly affects the nitrogen cycle.

\section{Conflicts of Interest}

The authors declare no conflicts of interest regarding the publication of this paper. 


\section{References}

[1] Lomsadze, Z., Makharadze, K., Tsitskishvili, M. and Pirtskhalava, R. (2017) Annals of Agrarian Science Water Resources of Kakheti and Ecological Problems. Annals of Agrarian Science, 15, 204-208. https://doi.org/10.1016/j.aasci.2017.03.002

[2] Lu, Y., Xu, H., Wang, Y. and Yang, Y. (2017) Evaluation of Water Environmental Carrying Capacity of City in Huaihe River Basin Based on the AHP Method: A Case in Huai'an City. Water Resources and Industry, 18, 71-77. https://doi.org/10.1016/j.wri.2017.10.001

[3] Négrel, P., Merli, C. and Gourcy, L. (2014) Soil-Sediment-River Connections: Catchment Processes Delivering Pressures to River Catchments. In: Risk-Informed Management of European River Basins, Springer, Berlin, 21-52. https://doi.org/10.1007/978-3-642-38598-8_2

[4] Chiogna, G., Majone, B., Paoli, K. and Kano, D. (2016) A Review of Hydrological and Chemical Stressors in the Adige Catchment and Its Ecological Status. Science of the Total Environment, 540, 429-443. https://doi.org/10.1016/j.scitotenv.2015.06.149

[5] Xie, Z., Sun, Z., Zhang, H. and Zhai, J. (2014) Contamination Assessment of Arsenic and Heavy Metals in a Typical Abandoned Estuary Wetland-A Case Study of the Yellow River Delta Natural Reserve. Environmental Monitoring and Assessment, 186, 7211-7232. https://doi.org/10.1007/s10661-014-3922-3

[6] Kanianska, R. (2016) Agriculture and Its Impact on Land-Use, Environment, and Ecosystem Services. In: Almusaed, A., Ed., Landscape Ecology_The Influences of Land Use and Anthropogenic Impacts of Landscape Creation, IntechOpen, London.

[7] Zerling, L., Hanisch, C. and Junge, F. (2006) Heavy Metal Inflow into the Floodplains of the Mouth of the River Weiße Elster (Central Germany). Acta Hydrochimica et Hydrobiologica, 34, 234-244. https://doi.org/10.1002/aheh.200400624

[8] Li, Y., Zhang, H., Chen, X., Tu, C., Luo, Y. and Christie, P. (2014) Distribution of Heavy Metals in Soils of the Yellow River Delta: Concentrations in Different Soil Horizons and Source Identification. Journal of Soils and Sediments, 14, 1158-1168. https://doi.org/10.1007/s11368-014-0861-0

[9] Fatoki, O., Muyima, N. and Lujiza, N. (2001) Situation Analysis of Water Quality in the Umtata River Catchment. Water $S A, 27,467-473$. https://doi.org/10.4314/wsa.v27i4.4959

[10] Tang, Q., Bao, Y., He, X., Zou, H. and Cao, Z. (2014) Sedimentation and Associated Trace Metal Enrichment in the Riparian Zone of the Three Gorges Reservoir, China. Science of the Total Environment, 479-480, 258-266. https://doi.org/10.1016/j.scitotenv.2014.01.122

[11] Finlayson, M., Cruz, R., Davidson, N. and Alder, J. (2005) Ecosystems and Human Well-Being: Wetlands and Water Synthesis.

[12] Litani River Authority (2019) The Characteristics of the Litani River. http://www.litani.gov.lb/en/?page_id=63

[13] Haydar, C.M., Nehme, N., Villeras, F. and Hamieh, T. (2014) Water Quality of the Upper Litani River Basin, Lebanon. Physics Procedia, 55, 279-284. https://doi.org/10.1016/j.phpro.2014.07.040

[14] Wazne, M. and Korfali, S. (2016) Spatial and Temporal Assessment of Metal Pollution in the Sediments of the Qaraoun Reservoir, Lebanon. Environmental Science and Pollution Research, 23, 7603-7614. https://doi.org/10.1007/s11356-015-6022-1 
[15] Khalifa, W.M.A., Abdel-Gawad, S.M. and Abdel-Hamid, N.M. (2012) Water Quality Simulation of Lake Qaroun Using Two Dimensional Models. Proceedings of the Water Environment Federation, Vol. 2001, 803-812. https://doi.org/10.2175/193864701790902347

[16] Diab, W. (2018) Étude des propriétés physico-chimiques et colloïdales du bassin de la rivière Litani, Liban Walaa Diab.

[17] Al-badaii, F., Shuhaimi-othman, M. and Gasim, M.B. (2013) Water Quality Assessment of the Semenyih River, Selangor, Malaysia. Journal of Chemistry, 2013, Article ID: 871054. https://doi.org/10.1155/2013/871056

[18] Zitko, V., Division, M.C., Branch, C.S. and Station, B. (1994) Principal Component Analysis in the Evaluation of Environmental Data. Marine Pollution Bulletin, 28, 718-722. https://doi.org/10.1016/0025-326X(94)90329-8

[19] Jolliffe, I.T. and Cadima, J. (2016) Principal Component Analysis: A Review and Recent Developments. Philosophical Transactions of the Royal Society A: Mathematical, Physical and Engineering Sciences, 374, Article ID: 20150202. https://doi.org/10.1098/rsta.2015.0202

[20] Feng, C., Tollin, G. and Enemark, J.H. (2007) Sulfite Oxidizing Enzymes. Biochimica et Biophysica Acta, 1774, 527-539.

https://doi.org/10.1016/j.bbapap.2007.03.006 